\title{
Evaluation of different probiotic strains for growth performance and immunomodulation in Pacific white shrimp Penaeus vannamei Boone, 1931
}

\author{
M. SUNDARAM, A. PANIGRAHI, J. GANESH, P. NILA REKHA, S. SIVAGNANAM, \\ S. RAJAMANICKAM AND C. GOPAL \\ ICAR-Central Institute of Brackishwater Aquaculture, 75 Santhome High Road, R. A. Puram, Chennai - 600028 \\ Tamil Nadu, India \\ e-mail:apanigrahi2k@gmail.com,panigrahi@ciba.res.in
}

\begin{abstract}
The use of antibiotics in aquaculture can prevent certain diseases, however, its use is highly restricted due to several environmental and human health problems like development of antibacterial resistance. Probiotics are widely used for improving production of aquatic animals by means of improving water quality as well as by nutritional and immune modulation in animals thus, helping in preventing diseases. The present study was aimed to evaluate different strains of probiotics viz., a commercial probiotic, Bacillus subtilis, Enterococcus sp., Lactobacillus casei, Lactobacillus rhamnosus, Saccharomyces cerevisiae and Saccharomyces boulardii on the growth, microbial load and immunomodulatory performance of the Pacific white shrimp, Penaeus vannamei. Seven probiotic feeds each containing $5 \times 10^{9} \mathrm{CFU} \mathrm{ml}^{-1}$ of respective probiotics $\mathrm{kg}^{-1}$ of feed were prepared by top coating on a pellet feed containing 35\% protein and duration of the experiment was 75 days. All of the 6 selected strains of probiotics except the commercial one influenced the growth significantly when fed to the shrimp, compared to control group. Specific growth rate (SGR), average daily growth (ADG) and survival rate were observed to be higher in probiotic fed groups. Maximum growth was recorded in S. cerevisiae fed groups $(8.05 \pm 0.21 \mathrm{~g})$, followed by B. subtilis $(7.65 \pm 0.21 \mathrm{~g})$, while the control animals showed an average growth of $4.85 \pm 0.49 \mathrm{~g}$ with percentage improvement in the range of $50-95 \%$ when compared to all other treatments. Total heterotrophic count significantly $(\mathrm{p}<0.05)$ increased in the rearing water of $B$. subtilis treated group $\left(8.995 \pm 0.021 \times 10^{3} \mathrm{cfu} \mathrm{ml}^{-1}\right)$ when compared to that of control $\left(5.475 \pm 0.003 \times 10^{3} \mathrm{cfu} \mathrm{ml}^{-1}\right)$ and total vibrio load was greatly reduced in $B$. subtilis $(1.42 \pm 0.04 \mathrm{x}$ $\left.10^{3} \mathrm{cfu} \mathrm{ml}^{-1}\right)$ and $S$. cerevisiae $\left(1.47 \pm 0.01 \times 10^{3} \mathrm{cfu} \mathrm{ml}^{-1}\right)$ treated water compared to control $\left(4.265 \pm 0.06 \times 10^{3} \mathrm{cfu} \mathrm{ml}^{-1}\right)$. Non-specific immunity in terms of total haemocyte count (THC) was found to be significantly $(\mathrm{p}<0.05)$ higher in B. subtilis $\left(12.4 \pm 0.810^{6}\right.$ cells ml $\left.^{-1}\right)$ treated group while higher $(\mathrm{p}<0.05)$ prophenoloxidase (pro PO) activity was recorded in S. cerevisiae $\left(0.132 \pm 0.001\right.$ units $\mathrm{min}^{-1} \mathrm{mg}$ protein $\left.{ }^{-1}\right)$ and B. subtilis $\left(0.130 \pm 0.002\right.$ units $\mathrm{min}^{-1} \mathrm{mg}$ protein $\left.{ }^{-1}\right)$ treated groups. The probiotic effect was found to be beneficial for better growth and immunomodulation, which was however found to be strain-specific.
\end{abstract}

Keywords: Immunity, Penaeus vannamei, Probiotics, Survival rate

\section{Introduction}

Shrimp farming has been plagued with infectious disease outbreaks from many bacterial and viral pathogens. Control strategies have been developed for emerging diseases for improving animal health, better production and environmental friendly sustainable culture. Antibiotics have been used in aquaculture for control of infectious diseases but these have enormous environmental, economic and social concerns. Probiotics are beneficial bacteria that promote the wellbeing of a host animal and contribute to the direct and/or indirect protection of host animals against harmful bacteria. These beneficial microbes favour the host by competitive inhibition of pathogenic microbes. The application of probiotic bacteria in aquaculture has tremendous scope, outputs and glorious future. Probiotic organisms are found to be the richest source of many beneficial products, such as vitamins, minerals and trace elements and important digestive enzymes thereby having nutritional benefits (Wang et al., 2005; Vo Minh Son et al., 2009). Probiotic treatment results in better survival, growth, disease resistance and improve the protective response especially during the larval stages in shrimps and fishes (Gullian et al., 2004).

Studies in fish and shellfishes have shown the beneficial effects of probiotics in enhancing the growth rate and survival (Panigrahi et al., 2005, 2007; Karunasagar, 2007). There are various studies elucidating the beneficial use of probiotics (bacterins) in crustaceans with encouraging results (Itami et al., 1989, 1991; Karunasagar et al., 1994; Devaraja et al., 2002; Azad et al., 2005). Several studies demonstrated improved survival and growth rate of shrimps reared with probiotics (Maeda, 1994; Austin et al., 1995; Azad et al., 2005). These beneficial microbes can be effectively used against the pathogenic Vibrio species, which is a major 
problem in shrimp hatcheries (Moriarty, 1998; Rengpipat et al., 1998; Otta et al., 2014). Apparently, probiotics serve as immunostimulants as well as immunomodulators which elicit the non-specific immunity in shrimps to fight infections and diseases. The mechanism by which probiotic bacteria enhance immunity of fish is still not completely elucidated to date though there are several studies (Irianto and Austin, 2002; Panigrahi et al., 2009, 2011).

Owing to the varied potential of probiotics, the present study was aimed to investigate the effect of selected probiotics (commercial, conventional and isolated bacterial cultures) on the growth performance and immunomodulation of pacific white-legged shrimp, Penaeus vannamei.

\section{Materials and methods}

Probiotics sourcing and mass production

The experiment was conducted using a commercially available probiotics (Cp) and 6 probiotics prepared from pure stains i.e., Bacillus subtilis (MTCC 2756), Lactobacillus rhamnosus (ATCC 53103), Lactobacillus casei (ATCC 335), Saccharomyces cerevisiae (IAM 14383T), Saccharomyces boulradi and Enterococcus sp. (MTCC 10646), Pure stains of $S$. boulradi were collected fron known sources from central labs including (ICAR-CIBA). For analysing the viability of the strains, the bacteria were cultured at $30^{\circ} \mathrm{C}$ for 24 to $36 \mathrm{~h}$ in specific media viz., tryptic soy agar (Merck, Darmstadt, Germany) for Bacillus subtilis; Enterococcus differential agar base (TITG Agar Base, HiMedia, USA) for Enterococcus sp.; MRS agar (Merck, Darmstadt, Germany) for Lactobacillus casei and Lactobacillus rhamnosus; Sabouraud dextrose agar (HiMedia, USA) for Saccharomyces cerevisiae and Saccharomyces boulardii and subsequently preserved in glycerin at $-80^{\circ} \mathrm{C}$ for further use. Later identification of these strains were confirmed using biochemical and molecular tools using $16 \mathrm{~S}$ ribosomal RNA. These potential probiotic strains were mass produced by Mystical Biotech Pvt. Ltd. Hoskote, Bangalore, India for further experimentation.

\section{Probiotic feed preparation}

Shrimp feed was formulated at ICAR-Central Institute of Brackishwater Aquaculture (ICAR-CIBA), Chennai as per Castex et al. (2006). Seven probiotic feeds were prepared by top coating of the respective probiotics (at a concentration of $5 \times 10^{9} \mathrm{CFU} \mathrm{g}^{-1}$ ) with every kilogram of feed using guar gum. The final concentration of probiotics in feed was maintained@5 x $10^{6} \mathrm{CFU} \mathrm{g}^{-1}$ of respective probiotics kg-1 of feed. The pellet feeds were prepared at the institute feed mill of ICAR-CIBA, Chennai and subsequently top coated with the respective probiotics to prepare the experimental feeds. The concentration of probionts in the feed was confirmed by spread plate method in the respective media as described earlier.

\section{Experimental design}

P. vannamei post-larvae (PL III) were purchased from Vaisakhi Shrimp Hatchery at Marakkanam, Tamil Nadu. The experiment was conducted at the Muttukadu Experimental Station of ICAR-CIBA, Chennai, in 1001 fibre-reinforced plastic (FRP) tanks $(50 \mathrm{~cm} \times 70 \mathrm{~cm} \times 35 \mathrm{~cm})$, with each treatment in triplicates. Each tank was stocked with $50 \mathrm{PL}$ of $P$. vannamei having mean initial weight of $0.08 \mathrm{~g}$. Water was exchanged $(20 \%)$ once in three days and water quality parameters were monitored regularly. The seawater used for rearing was ideal for $P$. vannamei culture with salinity of $33 \pm 1.0$ ppt. The aeration was optimum ensuring dissolved oxygen (DO) levels in the range of 7 to $8 \mathrm{ppm}$. The experiment was conducted for a period of 75 days during which the PLs were fed with probiotics supplemented diet @ $4 \%$ of the body weight twice a day at 0800 and 1800 hrs.

\section{Assessment of physico-chemical parameters}

Seawater $(33 \pm 1.0 \mathrm{ppt})$ was used for rearing shrimps. Water quality was checked on weekly basis. Water parameters such as temperature (mercury thermometer), $\mathrm{pH}$ (pH-ScanEutech instruments, Singapore), total ammonia nitrogen (TAN) (Phenol hypochlorite method), $\mathrm{NO}_{2}-\mathrm{N}, \mathrm{NO}_{3}-\mathrm{N}$ and dissolved oxygen (DO) were analysed following APHA (1998).

\section{Assessment of growth performance}

The growth performance of shrimps was recorded once in 15 days by measuring the length and weight followed by estimation of survival rate, specific growth rate (SGR) and average daily growth (ADG) using the following formulae:

$$
\begin{aligned}
& \text { Weight gain }(\%)=\begin{array}{l}
\text { Final weight }(\mathrm{g}) \text {-Initial weight }(\mathrm{g}) / \text { Initial weight } \\
(\mathrm{mg})
\end{array} \\
& \text { Length gain }(\%)=\begin{array}{l}
\text { Final length }(\mathrm{mm}) \text {-Initial length }(\mathrm{mm}) / \\
\text { Initial length }(\mathrm{mm}) \times 100
\end{array} \\
& \mathrm{SGR}(\%) \quad \begin{array}{l}
\text { In final weight-In initial weight }) / \text { Days of culture } \\
\times 100
\end{array} \\
& \mathrm{ADG}\left(\mathrm{g} \mathrm{day}^{-1}\right)=\begin{array}{l}
\text { Final weight }(\mathrm{mg})-\text { Initial weight }(\mathrm{mg}) / \\
\text { Experimental duration }(\text { days })
\end{array} \\
& \text { Survival }(\%)=\begin{array}{l}
\text { Shrimp no. at the end of experiment } / \text { Shrimp no. } \\
\text { at the beginning of experiment } \times 100
\end{array}
\end{aligned}
$$

\section{Assessment of microbial load}

The total heterotrophic bacteria were determined in the shrimp rearing water by counting the colonies which grew on plates of Zobell Marine Agar (ZMA) (Hi-Media) with 1\% of $\mathrm{NaCl}$ (Jorgensen et al., 1993). Before plating each sample 
onto agar medium, serial dilutions were made in physiological saline $(0.9 \% \mathrm{NaCl})$ solution (Sohier and Bianchi, 1985). The total Vibrio count in water samples were enumerated using thiosulphate citrate bile salt sucrose (TCBS) agar (Hi-Media) by spread plate technique as previously described (Harris et al., 1996). The bacterial counts were expressed in colony forming units per $\mathrm{ml}$ of water (CFU ml-1) (Smith, 1998).

\section{Collection and analysis of haemolymph}

Physiological saline was prepared by dissolving $\mathrm{NaCl}$ (340 mm), $\mathrm{KCl}(13 \mathrm{~mm}), \mathrm{MgSO}_{4}(11 \mathrm{~mm}), \mathrm{MgCl}_{2}(10 \mathrm{~mm})$, $\mathrm{NaH}_{2} \mathrm{PO}_{4}(0.3 \mathrm{~mm})$ and glucose $(1.6 \mathrm{~mm})$ in $100 \mathrm{ml}$ distilled water and $\mathrm{pH}$ was adjusted to 7.8 using $\mathrm{NaHCO}_{3}$ (Hi-Media) Anticoagulant saline (ACS) was prepared by adding $3 \mathrm{mg}$ cysteine in $5 \mathrm{ml}$ of physiological saline. Hemolymph samples from probiotics treated and control shrimps were withdrawn from heart using $21 \mathrm{G}$ needle attached to a $2 \mathrm{ml}$ sterile polypropylene syringe containing $1 \mathrm{ml}$ of ice-cold cysteine anticoagulant saline. After hemolymph collection, the syringe was withdrawn from the animal and shaken gently to assist the rapid mixing of hemolymph and ACS.

\section{Total haemocyte count}

Haemolymph $(100 \mu \mathrm{l})$ was withdrawn from the ventral sinus of the first abdominal segment into a syringe containing anti-coagulant saline $(900 \mu \mathrm{l})$ and transferred to an eppendorf tube for total haemocyte count (THC). The THC was measured according to modified method from Soderhall and Smith (1983). Briefly, $10 \mu \mathrm{l}$ of haemolymph collected from each individual was introduced into an improved Neubauer haemocytometer and the number of haemocytes was determined microscopically.

\section{Phenoloxidase activity assay}

Haemolymph samples were collected from control and probiotic treated shrimps by cardiac puncture using a sterile syringe. The haemolymph samples thus collected were transferred to microcentrifuge tubes held on ice and allowed to clot for $30 \mathrm{~min}$ at room temperature $\left(28 \pm 2^{\circ} \mathrm{C}\right)$. The clot was disturbed using a clean glass rod and then centrifuged at $1500 \mathrm{rpm}$ for $7 \mathrm{~min}$. The clear supernatant (serum) thus collected was used for phenoloxidase activity as per Smith and Soderhall (1983).

\section{Statistical analysis}

All results are presented as the average (mean \pm SD) of at least three independent experiments. Student's t-test, analysis of variance (ANOVA) and the Duncan's multiple range tests were used for statistical analyses of the data $(p<0.05)$ performed using SPSS for Windows version 20.0.

\section{Results and discussion}

Reports on the efficacy of probiotics on the growth and survival of the domesticated shrimp, $P$. vannamei are inadequate. In this context, the present study was conducted to investigate the effect of six different probiotic bacteria and a commercial preparation on the growth performance, survival and immunomodulation of . vannamei. Application of B. subtilis as probiotic has brought very promising results for shrimp aquaculture. This is a nonpathogenic Gram positive spore-forming bacterium which has been used to improve the growth performance, as well as shrimp health and disease management in shrimp farming (Balcazar et al., 2007; Keysami et al., 2012). In addition, it is well documented that Bacillus sp. are able to produce a wide range of extracellular substances and antimicrobial peptides against a variety of microorganisms (Perez et al., 1993; Korenblum et al., 2005). S. cerevisiae is a potential supplement in shrimp feeds (Gabriel AguirreGuzma'n et al., 2002) and has been reported to have beneficial effects in the shrimp growth performance, immunity and ability to improve water quality. The results of the present study indicated a significant $(p<0.05)$ improvement in growth in terms of weight and length in all the probiotic fed groups (Table 1). An increase of $50-95 \%$ growth was observed in probiotic fed groups with maximum increase in $S$. cerevisiae $(8.05 \pm 0.21 \mathrm{~g})$, followed by B. subtilis $(7.65 \pm 0.21 \mathrm{~g})$ and other probiotic treated groups $(\mathrm{Sb}=7.00 \pm 0.28, \mathrm{Lr}=6.30 \pm 0.14$, $\mathrm{Lc}=6.2 \pm 0.28$ and Ent. $=5.1 \pm 0.14 \mathrm{~g})$ whereas the control showed lower growth of $4.85 \pm 0.49 \mathrm{~g}$ (Fig. 1).

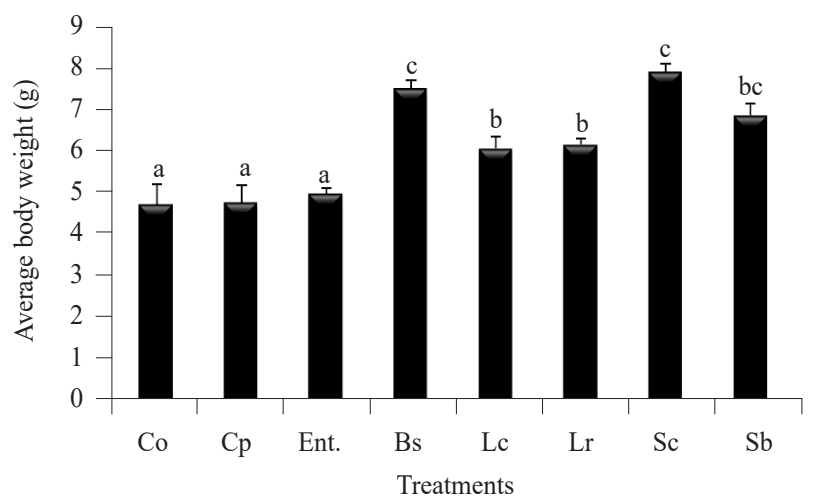

Fig. 1. Average body weight of $P$. vannamei fed probiotic incorporated and control diets. Data expressed as mean \pm S.D. Groups with different superscript letters differ significantly.

A similar trend was also observed in the average body length $(\mathrm{ABL})$ of shrimps fed with different probiotics (Table 1). Several authors reported better growth performances in probiotic treated shrimps when compared to control groups (Intriago et al., 1998; Rengpipat et al., 1998; Wang et al., 2007).

The survival rate of $P$. vannamei, treated with probiotic $S$. cerevisiae was found to be the highest $(65.5 \pm 0.7 \%)$, followed by other groups such as Bs $(59.0 \pm 1.4 \%)$, $\mathrm{Sb} \quad(56.5 \pm 0.7 \%), \quad \operatorname{Lr} \quad(54.5 \pm 0.7 \%), \quad$ Lc $\quad(52.5 \pm 2.1 \%)$, 
Table 1. Growth performance of $P$. vannamei fed probiotic incorporated and control diets for a period of 75 days

\begin{tabular}{|c|c|c|c|c|c|c|c|c|}
\hline Treatments & $\begin{array}{l}\text { Initial } \\
\text { weight } \\
\text { (g) }\end{array}$ & $\begin{array}{l}\text { ABW } \\
\text { (g) }\end{array}$ & $\begin{array}{l}\text { Weight } \\
\text { improvement } \\
(\%)\end{array}$ & $\begin{array}{l}\text { Initial } \\
\text { length } \\
(\mathrm{mm})\end{array}$ & $\begin{array}{l}\mathrm{ABL} \\
(\mathrm{mm})\end{array}$ & $\begin{array}{l}\text { Length } \\
\text { improvement } \\
(\%)\end{array}$ & $\begin{array}{l}\text { SGR } \\
(\%)\end{array}$ & $\begin{array}{l}\text { ADG } \\
\left(\mathrm{g} \mathrm{day}^{-1}\right)\end{array}$ \\
\hline $\mathrm{CO}$ & $0.08 \pm 0.00^{\mathrm{a}}$ & $4.85 \pm 0.49^{\mathrm{a}}$ & - & $15.7 \pm 0.06^{\mathrm{a}}$ & $63.0 \pm 1.41^{\mathrm{a}}$ & - & $2.08 \pm 0.14^{\mathrm{a}}$ & $0.062 \pm 0.004^{\mathrm{a}}$ \\
\hline $\mathrm{Cp}$ & $0.08 \pm 0.01^{\mathrm{a}}$ & $4.90 \pm 0.42^{\mathrm{a}}$ & $1.0 \pm 0.52^{\mathrm{a}}$ & $15.6 \pm 0.06^{\mathrm{a}}$ & $64.0 \pm 1.23^{\mathrm{a}}$ & $1.5 \pm 0.06^{\mathrm{a}}$ & $2.09 \pm 0.12^{\mathrm{a}}$ & $0.064 \pm 0.002^{\mathrm{a}}$ \\
\hline Ent & $0.08 \pm 0.00^{\mathrm{a}}$ & $5.10 \pm 0.14^{\mathrm{a}}$ & $5.2 \pm 1.2^{\mathrm{a}}$ & $15.8 \pm 0.08^{\mathrm{a}}$ & $65.0 \pm 1.41^{\mathrm{a}}$ & $3.1 \pm 0.05^{\mathrm{a}}$ & $2.15 \pm 0.04^{\mathrm{a}}$ & $0.065 \pm 0.004^{\mathrm{a}}$ \\
\hline Bs & $0.08 \pm 0.01^{\mathrm{a}}$ & $7.65 \pm 0.21^{\mathrm{c}}$ & $57.7 \pm 2.7^{\mathrm{c}}$ & $15.6 \pm 0.09^{\mathrm{a}}$ & $97.5 \pm 2.12^{c}$ & $54.4 \pm 0.47^{\mathrm{bc}}$ & $2.70 \pm 0.04^{b}$ & $0.104 \pm 0.002^{\mathrm{c}}$ \\
\hline Lc & $0.08 \pm 0.00^{\mathrm{a}}$ & $6.20 \pm 0.28^{b}$ & $27.8 \pm 1.2^{\mathrm{b}}$ & $15.8 \pm 0.04^{\mathrm{a}}$ & $72.5 \pm 0.71^{\mathrm{b}}$ & $15.0 \pm 0.06^{\mathrm{b}}$ & $2.44 \pm 0.03^{\mathrm{ab}}$ & $0.082 \pm 0.001^{\mathrm{b}}$ \\
\hline $\mathrm{Lr}$ & $0.08 \pm 0.00^{\mathrm{a}}$ & $6.30 \pm 0.14^{b}$ & $29.9 \pm 1.2^{\mathrm{b}}$ & $15.5 \pm 0.00^{\mathrm{a}}$ & $75.5 \pm 0.71^{b}$ & $19.8 \pm 0.03^{b}$ & $2.41 \pm 0.06^{\mathrm{ab}}$ & $0.083 \pm 0.001^{b}$ \\
\hline $\mathrm{Sc}$ & $0.08 \pm 0.00^{\mathrm{a}}$ & $8.05 \pm 0.21^{\mathrm{c}}$ & $66.0 \pm 3.2^{\mathrm{c}}$ & $15.7 \pm 0.08^{\mathrm{a}}$ & $103.5 \pm 0.71^{\mathrm{c}}$ & $64.2 \pm 0.06^{\mathrm{c}}$ & $2.77 \pm 0.04^{\mathrm{b}}$ & $0.106 \pm 0.002^{\mathrm{c}}$ \\
\hline $\mathrm{Sb}$ & $0.08 \pm 0.00^{\mathrm{a}}$ & $7.00 \pm 0.28^{b c}$ & $44.3 \pm 1.2^{\mathrm{bc}}$ & $15.7 \pm 0.00^{\mathrm{a}}$ & $92.5 \pm 0.71^{\mathrm{bc}}$ & $46.8 \pm 0.09^{\mathrm{ab}}$ & $2.58 \pm 0.05^{\mathrm{ab}}$ & $0.092 \pm 0.002^{\mathrm{bc}}$ \\
\hline
\end{tabular}

Data expressed as mean \pm S.D. Means with different superscript letters in the column differ significantly $(\mathrm{p}<0.05)$

$\mathrm{CO}$ : Control, $\mathrm{Cp}$ : Commercial probiotic, Ent : Enterococcus sp., Bs : Bacillus subtilis, Lc : Lactobacillus casei, Lr : Lactobacillus rhamnosus, Sc : Saccharomyces cerevisiae, Sb : Saccharomyces boulardii. Control : Without addition of probiotics, SGR : Specific growth rate, ADG : Average daily growth

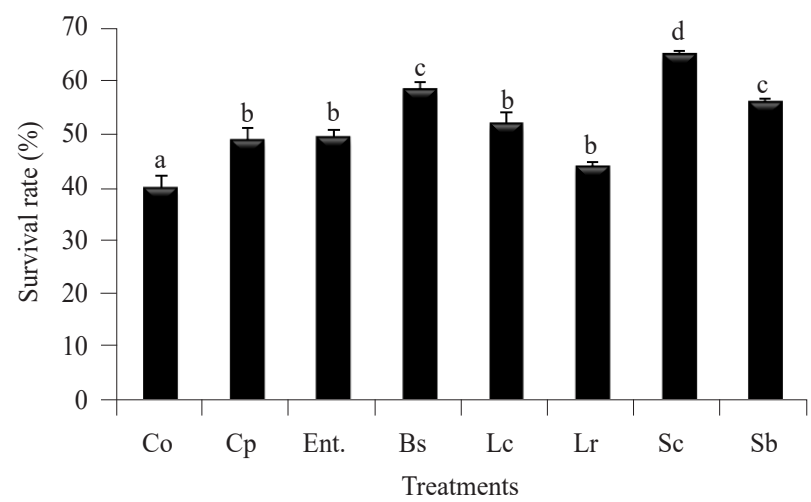

Fig. 2. Average survival \% of juvenile Pacific white shrimp reared with different probiotic feeds. Data expressed as mean \pm S.D. Groups with different superscript letters differs significantly

Ent $(49.9 \pm 1.4 \%)$ and $\mathrm{Cp}(49.5 \pm 2.1 \%)$ compared to control (40.5 $\pm 2.1 \%$ (Fig. 2).

Moriarty (1998) has reported increased shrimp survival in the pond water inoculated with Bacillus species. This was attributed to the water quality improvement by the bacterial inoculations, due to degradation of organic matter. In accordance with our results, there are also reports of enhancement in shrimp performance when probiotics are used as feed additives (Wang et al., 2005; De Souza et al., 2012; Silva et al., 2012). The SGR of P. vannamei was observed to be maximum in $S$. cerevisiae treated group $(10.6 \pm 0.03 \%)$ followed by $\mathrm{Bs}>\mathrm{Lc}>\mathrm{Lr}>\mathrm{Sb}>\mathrm{Ent}>\mathrm{Cp}$ (Table 1$)$. Average daily growth (ADG) was high in $S$. cerevisiae $(0.106 \pm 0.002 \mathrm{~g})$ and B. subtilis $(0.104 \pm 0.002 \mathrm{~g})$ followed by other strains such as $\mathrm{Sb}(0.092 \pm 0.002 \mathrm{~g}), \mathrm{Lc}(0.083 \pm$ $0.001 \mathrm{~g}), \operatorname{Lr}(0.082 \pm 0.001 \mathrm{~g})$, Ent $(0.065 \pm 0.004)$ and $\mathrm{Cp}$ $(0.064 \pm 0.002 \mathrm{~g})$ whereas in control it was observed to be the lowest $(0.062 \pm 0.004 \mathrm{~g})$. Similar to our findings, several studies have demonstrated the beneficial effects of probiotics on the growth performance in shrimp (Wang et al., 2007; Shen et al., 2010; Liu et al., 2009).
Further, non-specific immune parameters in terms of THC and proPO showed strain specific enhancement in probiotic treated groups (Smith and Soderhall, 1983). Haemocytes play vital role in the immune response in crustaceans. Probiotic S. cerevisiae were found to trigger the haemocytes and in turn the immune system in the test animals (Ratcliffe and Rowley, 1979; Soderhall et al., 1984). The THC was found to be high in the S. cerevisiae (12.4 \pm 0.8 ) $\mathrm{x} 10^{6}$ cells $\mathrm{ml}^{-1}$ ) and other probiotic treated groups of Pacific white shrimp $(\mathrm{Bs}=11.2 \pm 0.8, \mathrm{Sb}=9.1 \pm 0.5$, $\mathrm{Lc}=8.8 \pm 0.4, \mathrm{Lr}=8.8 \pm 0.4$, Ent. $=7.1 \pm 0.8$ and $\mathrm{Cp}=6.2 \pm 0.8$ $\mathrm{X} 10^{6}$ cells ml $\left.{ }^{-1}\right)$ compared to that observed in control (5.2 \pm 0.9 $\mathrm{X} 10^{6}$ cells $\left.\mathrm{ml}^{-1}\right)(\mathrm{p}<0.05)$ (Fig. 3).

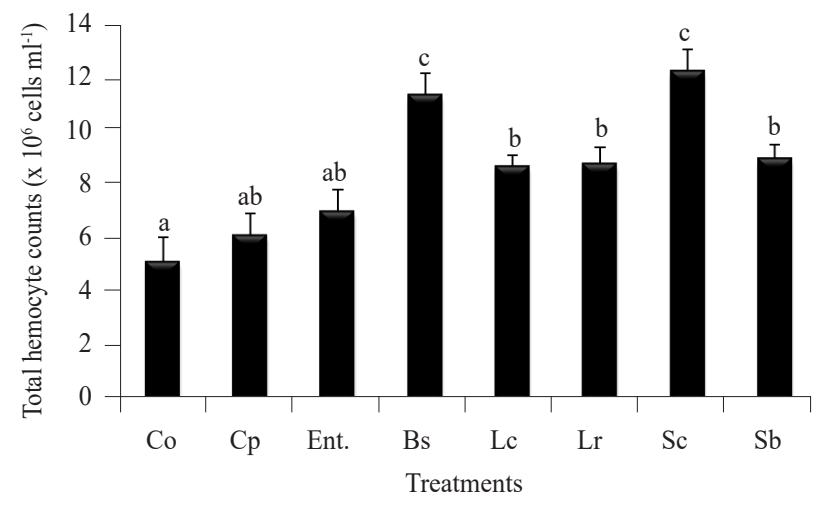

Fig. 3. Average total haemocyte count $\left(\times 10^{6}\right.$ cells $\left.\mathrm{ml}^{-1}\right)$ of juvenile Pacific white shrimp sub adult stage $(n=6)$ reared with different probiotic feeds. Data expressed as mean \pm S.D. Groups with different superscript letters differ significantly.

The proPO activating system has a fundamental role in organising the innate immune response in invertebrates (Soderhall and Cerenius, 1998). Enhanced phenoloxidase activity in probiotic treated groups clearly demonstrates shrimps' ability to respond to external challenges (Lee and Soderhall, 2002). The pro PO system plays a critical role in 
host defensive reactions, which could be activated by some microbial lipopolysaccharides and $\beta$-1,3-glucan to generate phenoloxidase (PO), an important enzyme in the process of melanisation (Gai et al., 2008; Figueroa-Pizano et al., 2014). The transcript levels of proPO generally corresponded to the activity monitored for the same enzyme (Gai et al., 2008). Furthermore, proPO activity was found to be significantly higher $(\mathrm{p}<0.05)$ in the $S$. cerevisiae probiotic fed $\left(0.132 \pm 0.001 \mathrm{U} \mathrm{min}^{-1} \mathrm{mg}\right.$ protein $\left.{ }^{-1}\right)$ group of $P$. vannamei and other probiotic groups $(\mathrm{Bs}=0.130 \pm 0.002, \mathrm{Lr}=0.125 \pm 0.005$, $\mathrm{Lc}=0.124 \pm 0.005, \mathrm{Sb}=0.110 \pm 0.005$, Ent. $=0.103 \pm 0.002$ and $\mathrm{Cp}=0.089 \pm 0.004 \mathrm{U} \mathrm{min}^{-1} \mathrm{mg}$ protein $\left.{ }^{-1}\right)$ when compared to control $\left(0.079 \pm 0.001 \mathrm{U} \mathrm{min}^{-1} \mathrm{mg}\right.$ protein $\left.^{-1}\right)$ (Fig. 4). Although several probiotic bacteria were reported to exert beneficial effects on PO activity in shrimp (Rengpipat et al., 2000; Tseng et al., 2009; Sapcharoen and Rengpipat, 2013), a few of them like B. subtilis BP11 did not show any siginificant effect on PO activity (Sapcharoen and Rengpipat, 2013).

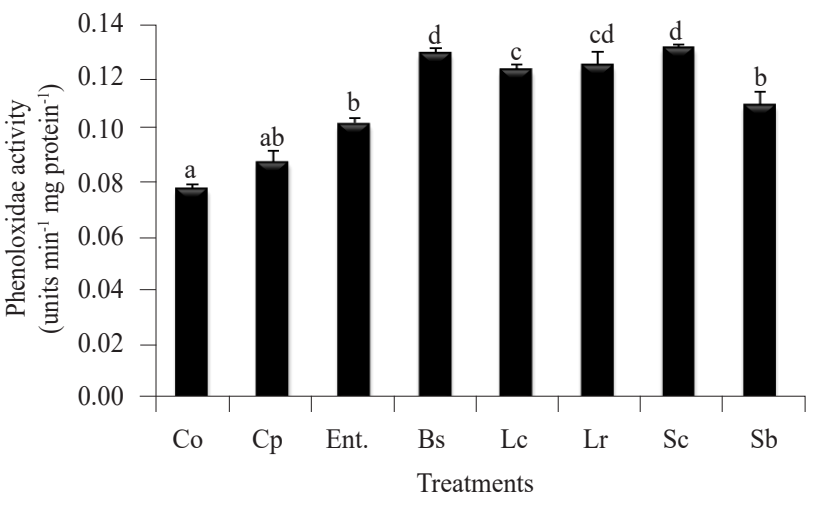

Fig. 4. Phenoloxidase activity (units $\min ^{-1} \mathrm{mg}$ protein ${ }^{-1}$ ) in juvenile Pacific white shrimp reared with different probiotic diets and control. Data expressed as mean \pm S.D. Groups with different superscript letters differ significantly.
Additionally, the probiotic treated groups also showed a drastic reduction in Vibrio count (Fig. 5a) and an increase in heterotrophic bacteria count (Fig. 5b). Further, the level of ammonia in rearing water decreased in the probiotic treated groups such as $S$. cerevisiae $(0.0 .106 \pm 0.0 \mathrm{ppm})$, Bs $(0.108 \pm 0.0 \mathrm{ppm}), \mathrm{Lc}(0.114 \pm 0.0 \mathrm{ppm}), \operatorname{Lr}(0.121 \pm 0.0$ $\mathrm{ppm})$, Ent $(0.124 \pm 0.0 \mathrm{ppm})$ and $\mathrm{Sb}(0.126 \pm 0.0 \mathrm{ppm})$. Similarly, nitrate and nitrite levels were found decreased in the probiotic treated groups i.e. S. cerevisiae $(0.018 \pm 0.001$ ppm) whereas in the control group, it was $0.089 \pm 0.005 \mathrm{ppm}$ (Table 2). There was a decrease in nitrite and nitrate concentration for probiotic treated group. $S$. cerevisiae treated group $(0.018 \pm 0.001 \mathrm{ppm})$ showed the lowest nitrite and nitrate levels compared to control $(0.089 \pm 0.005 \mathrm{ppm})$ and other treatments (Table 2).

These parameters provide a favourable environment for shrimp growth and survival. Water quality parameters such as temperature, $\mathrm{pH}$, salinity, dissolved oxygen and phosphate ranged from 27 to $28^{\circ} \mathrm{C}, 8.17$ to $8.27,32.0$ to $33.0 \mathrm{ppt}, 8.13$ to $8.53 \mathrm{ppm}$ and 0.070 to $0.082 \mathrm{ppm}$ respectively in probiotic fed group and no significant $(\mathrm{p}<0.05)$ difference were found compared to that of the control.

Wang et al. (2005) reported reduction of the nitrogen and phosphorous levels in $P$. vannamei ponds using the same microorganisms. However, the TAN, nitrite- $\mathrm{N}$ and nitrate-N levels were decreased in the probiotic treated tanks (Table 2). Our results suggest the plausible role of probiotics in improving the water quality in aquaculture ponds. Probiotic products used in aquaculture ponds were reported to give better overall growth and water quality (Rengpipat et al., 1998; Das et al., 2006; Zhu et al., 2009). The degradation of organic matter by probiotics like Bacillus sp. might help to improve water quality (Gatesoupe, 1999).

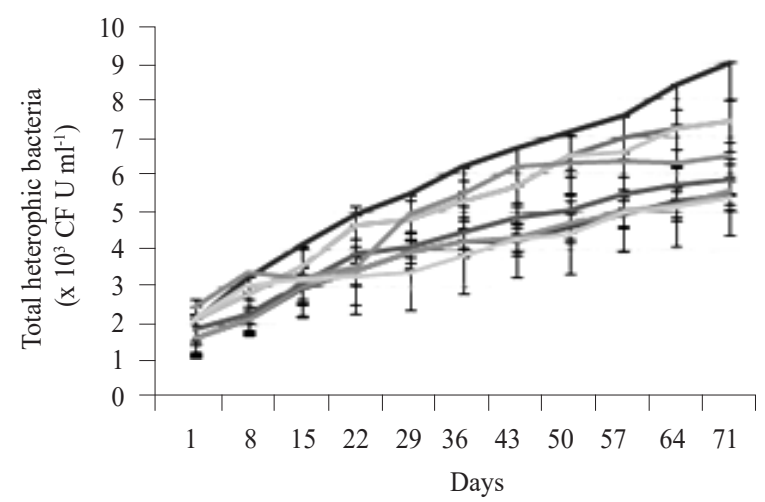

(a)

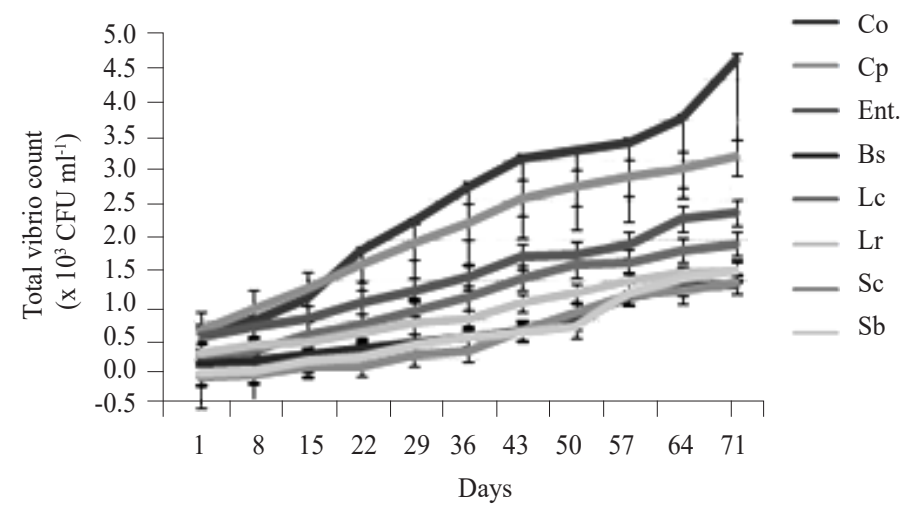

(b)

Fig. 5. Reduction of vibrio count (a) in the probiotic fed group when compared to the control and increase in the total bacterial count (b) in the probiotic fed groups 
Table 2. Physico-chemical parameters of water in the experimental tanks of P. vannamei fed probiotic incorporated and control diets

\begin{tabular}{lllllllll}
\hline Treatments & $\begin{array}{l}\text { Temperature } \\
\left({ }^{\circ} \mathrm{C}\right)\end{array}$ & & $\begin{array}{l}\text { Salinity } \\
(\mathrm{ppt})\end{array}$ & $\begin{array}{l}\mathrm{TAN} \\
(\mathrm{ppm})\end{array}$ & $\begin{array}{l}\mathrm{NO}_{2} \\
(\mathrm{ppm})\end{array}$ & $\begin{array}{l}\mathrm{NO}_{3} \\
(\mathrm{ppm})\end{array}$ & $\begin{array}{l}\mathrm{PO}_{4} \\
(\mathrm{ppm})\end{array}$ & $\begin{array}{l}\mathrm{DO} \\
(\mathrm{ppm})\end{array}$ \\
\hline $\mathrm{CO}$ & $28.0 \pm 0.0^{\mathrm{a}}$ & $8.33 \pm 0.02^{\mathrm{a}}$ & $33.0 \pm 0.0^{\mathrm{a}}$ & $0.500 \pm 0.0^{\mathrm{a}}$ & $0.044 \pm 0.0^{\mathrm{a}}$ & $0.071 \pm 0.005^{\mathrm{a}}$ & $0.084 \pm 0.003^{\mathrm{a}}$ & $8.74 \pm 0.29^{\mathrm{a}}$ \\
$\mathrm{Cp}$ & $28.0 \pm 0.0^{\mathrm{a}}$ & $8.27 \pm 0.01^{\mathrm{ab}}$ & $33.0 \pm 0.0^{\mathrm{a}}$ & $0.247 \pm 0.0^{\mathrm{b}}$ & $0.018 \pm 0.0^{\mathrm{b}}$ & $0.021 \pm 0.004^{\mathrm{b}}$ & $0.082 \pm 0.002^{\mathrm{a}}$ & $8.74 \pm 0.29^{\mathrm{a}}$ \\
$\mathrm{Ent}$ & $28.0 \pm 0.0^{\mathrm{a}}$ & $8.24 \pm 0.04^{\mathrm{ab}}$ & $33.0 \pm 0.0^{\mathrm{a}}$ & $0.124 \pm 0.0^{\mathrm{ab}}$ & $0.020 \pm 0.0^{\mathrm{a}}$ & $0.019 \pm 0.001^{\mathrm{b}}$ & $0.080 \pm 0.002^{\mathrm{a}}$ & $8.74 \pm 0.29^{\mathrm{a}}$ \\
$\mathrm{Bs}$ & $28.0 \pm 0.0^{\mathrm{a}}$ & $8.22 \pm 0.01^{\mathrm{ab}}$ & $33.0 \pm 0.0^{\mathrm{a}}$ & $0.108 \pm 0.0^{\mathrm{c}}$ & $0.011 \pm 0.0^{\mathrm{b}}$ & $0.005 \pm 0.001^{\mathrm{c}}$ & $0.070 \pm 0.002^{\mathrm{a}}$ & $8.13 \pm 1.15^{\mathrm{a}}$ \\
$\mathrm{Lc}$ & $28.0 \pm 0.0^{\mathrm{a}}$ & $8.18 \pm 0.01^{\mathrm{b}}$ & $33.0 \pm 0.0^{\mathrm{a}}$ & $0.114 \pm 0.0^{\mathrm{c}}$ & $0.018 \pm 0.0^{\mathrm{b}}$ & $0.015 \pm 0.001^{\mathrm{b}}$ & $0.077 \pm 0.001^{\mathrm{a}}$ & $8.53 \pm 0.00^{\mathrm{a}}$ \\
$\mathrm{Lr}$ & $28.0 \pm 0.0^{\mathrm{a}}$ & $8.17 \pm 0.01^{\mathrm{b}}$ & $33.0 \pm 0.0^{\mathrm{a}}$ & $0.121 \pm 0.0^{\mathrm{ab}}$ & $0.018 \pm 0.0^{\mathrm{b}}$ & $0.015 \pm 0.004^{\mathrm{b}}$ & $0.078 \pm 0.001^{\mathrm{a}}$ & $8.53 \pm 0.00^{\mathrm{a}}$ \\
$\mathrm{Sc}$ & $28.0 \pm 0.0^{\mathrm{a}}$ & $8.19 \pm 0.01^{\mathrm{b}}$ & $33.0 \pm 0.0^{\mathrm{a}}$ & $0.106 \pm 0.0^{\mathrm{c}}$ & $0.007 \pm 0.0^{\mathrm{c}}$ & $0.003 \pm 0.001^{\mathrm{c}}$ & $0.074 \pm 0.002^{\mathrm{a}}$ & $8.33 \pm 0.29^{\mathrm{a}}$ \\
$\mathrm{Sb}$ & $28.0 \pm 0.0^{\mathrm{a}}$ & $8.18 \pm 0.28^{\mathrm{b}}$ & $33.0 \pm 0.0^{\mathrm{a}}$ & $0.126 \pm 5.0^{\mathrm{ab}}$ & $0.021 \pm 0.0^{\mathrm{b}}$ & $0.010 \pm 0.001^{\mathrm{b}}$ & $0.077 \pm 0.001^{\mathrm{a}}$ & $8.33 \pm 0.29^{\mathrm{a}}$ \\
\hline
\end{tabular}

Values are mean of triplicate groups and presented as mean \pm SE. Values with different superscripts in the same row are significantly different $(\mathrm{p}<0.05)$

Moriarty (1998) found that the use of probiotics could prevent luminescent Vibrio infection by either lowering or completely eliminating luminous vibrios in pond water and sediment. Devaraja et al. (2002) reported that B. subtilis and $S$. cerevisiae treated groups had a significantly higher concentration of total heterotrophic bacteria when compared to other treatments. The present study showed that the microbial loads were significantly altered in the treated groups and the heterotrophic bacterial (THB) counts in the rearing water were also significantly $(p<0.05)$ higher in treated groups than the control indicating their dominance in the culture system (Fig. 5a). Interestingly, the Vibrio counts were drastically declined in the all the probiotic fed groups indicating the plausible dominance of THB over the pathogenic Vibrio spp. (Fig. 5b).

In conclusion, the present study highlights the importance of various probiotics in improving the growth and survivability of $P$. vannamei post-larvae. Better performance was observed in groups fed with probiotic incorporated diets like Saccharomyces cerevisiae, B. subtilis, S. boulardii, L. casei and L. rhamnosus when compared to control. Probiotic treatment has also shown to elicit the cellular and humoral immunity in the tested animals, thus explaining the mechanism of action of these probionts. Hence, we propose that the probiotics particularly S. cerevisiae and B. subtilis have the potential to be used in shrimp culture owing to their beneficial effects. Further study is warranted to clearly understand the target pathways and the mechanism of action of probiotics in shrimps.

\section{Acknowledgements}

The authors are grateful to the Director, ICAR-CIBA, Chennai for providing the facilities.

\section{References}

APHA/AWWA/WPCF 1998. Standard methods for the examination of water and waste water, $20^{\text {th }}$ edn., American Public Health Association, Washington, DC, USA, 1325 pp.

Austin, B., Stuckey, K. F., Robertson, P. A., Efendi, I. and Griffith, D. R. W. 1995. A probiotic strain of Vibrio alginolyticus effective in reducing diseases caused by Aeromonas salmonicida, Vibrio anguillarum and Vibrio ordalii. J. Fish Dis., 18: 93-96.

Azad, I. S., Panigrahi, A., Gopal, C., Paulpandi, S., Mahima, C. and Ravichandran, P. 2005. Routes of immunostimulation vis-a vis survival and growth of Penaeus monodon (Fabricius) post-larvae. Aquaculture, 248: 227-234.

Balcazar, J. L. and Rojas-Luna, T. 2007. Inhibitory activity of probiotic Bacillus subtilis UTM126 against vibrio species confers protection against vibriosis in juvenile shrimp (Litopenaeus vannamei). Curr. Microbiol., 55: 409-412.

Castex, M., Chim, L., Wabete, N., Lemaire, P. and Usache, V. 2006. Feeding evaluation of probiotic bacteria Pediococcus acidilactici (Bactocell $\AA$ ) in subadult shrimp Litopenaeus stylirostris: microbial, nutritional and zootechnical aspects. In: Book of Abstract, WAS Annual Meeting, Florenze, Italia.

Das, S., Lyla, P. S. and Khan, S. A. 2006. Application of Streptomyces as a probiotic in the laboratory culture of Penaeus monodon (Fabricius). Isr. J. Aquac. Bamidgeh, 58: 198-204.

De Souza, D. M., Suita, S. M., Leite, F. P. L., Romano, L. A., Wasielesky, W. and Ballester, E. L. C. 2012. The use of probiotics during the nursery rearing of the pink shrimp Farfantepenaeus brasiliensis (Latreille, 1817) in a zero exchange system. J. Aquac. Res., 43: 1828-1837.

Devajara, T. N., Yusoff, F. and Shariff, M. 2002. Changes in bacterial populations and shrimp production in ponds treated with commercial microbial products. Aquaculture, 206(3-4): 254-256.

Guzman, G. A., Marie, D. R. and Suarez, L. E. C. 2002. Survival of agglomerated Saccharomyces cerevisiae in pelleted shrimp feeds. Aquaculture, 208: 125- 135.

Gai, Y. C., Zhao, J. M., Song, L. S., Li, C. H., Zheng, P. L., Qiu, L. M. and $\mathrm{Ni}$, D. J. 2008. A prophenoloxidase from the Chinese mitten crab Eriocheir sinensis: gene cloning, expression and activity analysis. Fish Shellfish Immunol., 24: 156-167.

Gatesoupe, F. J. 1999. The use of probiotics in aquaculture. Aquaculture, 180: 147-165. 
Gullian, M., Thompson, F. and Rodriguez, J. 2004. Selection of probiotic bacteria and study of their immunostimulatory effect in Penaeus vannamei. Aquaculture, 233: 1-14.

Harris, L., Owens, L. and Smith, S. 1996. A selective and differential medium for $V$. harveyi. Appl. Environ. Microbiol., 62: 3548-3550.

Intriago, P., Kraussand, E. and Barniol, R. 1998. The use of yeast and fungi as probiotics in Penaeus vannamei larviculture. In: Book of Abstracts, International Triennial Conference and Exposition, World Aquaculture Society, National Shellfish Association and American Fisheries Society, Las Vegas 15-19 February, 1998, Nevada, USA, 263 pp.

Irianto, A. and Austin, B. 2002. Probiotics in aquaculture. J. Fish Dis., 25: 633-642.

Itami, T., Takahashi, Y., Yoneoka, K. and Yan, Y. 1991. Survival of larval giant tiger prawns Penaeus monodon after addition of killed Vibrio cells to a microencapsulated diet. J. Aquat. Anim. Health, 3: 151-152.

Itami, T., Takahashi, Y. and Nakamura, Y. 1989. Efficacy of vaccination against vibriosis in cultured kuruma prawns Penaeus japonicus. J. Aquat. Anim. Health, 1: 238-242.

Jorgenson, N. O. G., Kroer, N., Coffin, R. B., Yang X. H. and Lee, C. 1993. Dissolved free amino acids, combined amino acids and DNA sources of carbon and nitrogen to marine bacteria. Mar. Ecol. Prog. Ser., 98: 135-148.

Karunasagar, I., Pai, R., Malathi, G. R. and Karunasagar, I. 1994. Mass mortality of Penaeus monodon larvae due to antibioticresistant Vibrio harveyi infection. Aquaculture, 128: 203-209.

Karunasagar, I., Shivu, M. M., Girisha, S. K., Krohne, G. and Karunasagar, I. 2007. Biocontrol of pathogens in shrimp hatcheries using bacteriophages. Aquaculture, 286: 288-292.

Keysami, M., Mohammadpour, M. and Saad, C. 2012. Probiotic activity of Bacillus subtilis in juvenile freshwater prawn, Macrobrachium rosenbergii (de Man) at different methods of administration to the feed. Aquac. Int., 20: 499-511.

Korenblum, E., von Der Weid, I., Santos, A. L. S., Rosado, A. S., Sebastián, G. V. and Coutinho, C. M. L. M. 2005. Production of antimicrobial substances by Bacillus subtilis LFE-1, $B$. firmus $\mathrm{H} 2 \mathrm{O}-1$ and B. licheniformis T6-5 isolated from an oil reservoir in Brazil. J. Appl. Microbiol., 98: 667-675.

Lee, S. and Soderhall, K. 2002. Early events in crustacean innate immunity. Fish Shellfish Immunol., 12: 421-437.

Liu, C. H., Chiu, C. S., Ho, P. L. and Wang, S. W. 2009. Improvement in the growth performance of white shrimp, Litopenaeus vannamei, by a protease-producing probiotic, Bacillus subtilis E20, from natto. J. Appl. Microbiol., 107: 1031-1041.

Maeda, M. 1994. Biocontrol of the larval rearing biotope in aquaculture. Bull. Natl. Res. Inst. Aquac., Supplement, $1: 71-74$

Moriarty, D. J. W. 1998. Control of luminous Vibrio species in penaeid aquaculture ponds. Aquaculture, 164: 351-358
Otta, S. K., Arulraj, R., Praveena, E. P., Manivel, R., Panigrahi, A., Bhuvaneswari, T., Ravichandran, P., Jithendran, K. P. and Ponniah, A. G. 2014. Association of dual viral infection with mortality of Pacific white shrimp (Litopenaeus vannamei) in culture ponds in India. Indian J. Virol., 25(1): 63-68.

Panigrahi, A., Kiron, V., Puangkaew, J., Kobayashi, T., Satoh, S. and Sugita, H. 2005. The viability of probiotic bacteria as a factor influencing the immune response in rainbow trout Oncorhynchus mykiss. Aquaculture, 243: 241-254.

Panigrahi, A., Kiron, V., Satoh, S., Hirono, I., Kobayashi, T., Aoki, T., Puangkaew, J. and Sugita, H. 2007. Immunomodulation and expression of immune related genes in rainbow trout Oncorhynchus mykiss fed probiotic-supplemented diets. Dev. Comp. Immunol., 31: 372-382.

Panigrahi, A., Azad, I. S., Das, B. K., Dandpat, J., Das, G., Behera, S. and Mishra, S. S. 2009. Probiotic induced immunomodulation: investigation into the cellular and molecular mechanism involved. Res. J. Biotechnol., 4 (3): 7-13.

Panigrahi, A., Viswanath, K. and Satoh, S. 2011. Real-time quantification of the immune gene expression in rainbow trout fed different forms of probiotic bacteria Lactobacillus rhamnosus. Aquac. Res., 42: 906-917.

Perez, C., Suarez, C. and Castro, G. 1993. Antimicrobial activity determined in strains of Bacillus circulans cluster. Folia Microbiol., 38: 25-28.

Ratcliffe, N. A. and Rowley, A. F. 1979. Comparative synopsis of the structure and function of the blood cells of insects and other invertebrates. Dev. Comp. Immunol., 3: 189-221.

Rengpipat, S., Phianphak, W., Piyatiratitivorkaul, S. and Menasveta P. 1998. Effects of probiotic bacterium in black tiger shrimp Penaeus monodon survival and growth. Aquaculture, 167: 301-313.

Rengpipat, S., Rukpratanporn, S., Piyatiratitivorakul, S. and Menasaveta, P. 2000. Immunity enhancement in black tiger shrimp (Penaeus monodon) by a probiont bacterium (Bacillus S11). Aquaculture, 191: 271-288.

Sapcharoen, P. and Rengpipat, S. 2013. Effects of the probiotic Bacillus subtilis (BP11 and BS11) on the growth and survival of Pacific white shrimp, Litopenaeus vannamei. Aquac. Nutr., 19: 946-954

Shen, W. Y., Fu, L. L., Li, W. F. and Zhu, Y. R. 2010. Effect of dietary supplementation with Bacillus subtilis on the growth, performance, immune response and antioxidant activities of the shrimp (Litopenaeus vannamei). Aquac. Res., 41: 1691-1698.

Smith, V. J., Soderhall, K. and Hamilton, M. 1984. $\beta$-1,3-glucan induced cellular defense reaction in the shore crab, Carcinus maenas. Comp. Biochem. Physiol., 77A: 636-639.

Smith, P. T. 1998. Effect of removing accumulated sediments on the bacteriology of ponds used to culture Penaeus monodon. Asian Fish. Sci., 10: 355-370. 
Silva, E. F., Sores, M. A., Calazans, N. F., Vogeley, J. L., do Valle, B. C., Soares, R. and Peixoto, S. 2012. Effect of probiotic (Bacillus spp.) addition during larvae and post-larvae culture of the white shrimp Litopenaeus vannamei. Aquac. Res., 44: $13-21$.

Soderhall, K. and Smith, V. J. 1983. Separation of hemocyte populations of Carcinus maenas and other marine decapods, and prophenoloxidase distribution. Dev. Comp. Immunol., 7: 229-239.

Soderhall, K., Vey, A. and Ramstedt, M. 1984. Hemocyte lysate enhancement of fungal spore encapsulation by crayfish hemocytes. Dev. Comp. Immunol., 8: 23-29.

Soderhall, K. and Cerenius, L. 1998. Role of the prophenoloxidaseactivating system in invertebrate immunity. Curr. Opin. Immunol., 10: 23-28.

Sohier, L. P. and Bianchi, M. A. G. 1985. Development of a heterotrophic bacterial community within a closed prawn aquaculture system. Microbial Ecol., 11: 353-369.
Son, V. M., Chang, C. C., Wu, M. C., Guu, Y. K., Chiu, C. H. and Cheng, W. 2009. Dietary administration of the probiotic, Lactobacillus plantarum, enhanced the growth, innate immune responses and disease resistance of the grouper Epinephelus coioides. Fish Shellfish Immunol., 26: 691-698.

Tseng, D. Y., Ho, P. L., Huang, S. Y., Cheng, S. C., Shiu, Y. L., Chiuand, C. S. and Liu, C. H. 2009. Enhancement of immunity and disease resistance in the white shrimp, Litopenaeus vannamei, by the probiotic, Bacillus subtilis E20. Fish Shellfish Immunol., 26: 339-344.

Wang, Y. B., Xu, Z. R. and Xia, M. S. 2005. The effectiveness of commercial probiotics in Northern white shrimp (Penaeus vannamei L.) ponds. Fish. Sci., 71: 1034-1039.

Wang, Y. B. and Han, J. Z. 2007. The role of probiotic cell wall hydrophobicity in bioremediation of aquaculture. Aquaculture, 269: 349-354.

Zhu, C. H., Zhu, G. Q., Musa, H. H., Seri, H. I. and Wu, S. L. 2009. The potential benefits of probiotics in animal production and health. J. Anim. Vet. Adv., 8: 313-321. 